\title{
ANALISA METODE SIMPLE MULTI ATTRIBUTE RATING TECHNIQUE (SMART) DAN SIMPLE ADDITIVE WEIGHTING (SAW) DALAM MENDUKUNG GERAKAN MASYARAKAT HIDUP SEHAT
}

\author{
Alif Catur Murti', Wiwit Agus Triyanto \\ ${ }^{1}$ Teknik Infromatika, Universitas Muria Kudus \\ ${ }^{2}$ Sistem Informasi, Universitas Muria Kudus \\ Email: ${ }^{2}$ alif.catur@umk.ac.id, ${ }^{2}$ at.wiwit@umk.ac.id
}

(Naskah masuk: 24 Juni 2021, diterima untuk diterbitkan: 30 Juni 2021)

\begin{abstract}
Abstrak
Berbagai metode Sistem Pendukung Keputusan(SPK) banyak digunakan dalam membantu menentukan langkah atau keputusan yang akan diambil. Metode seperti SAW, TOPSIS, PROMETHEE, WP, AHP, SMART adalah beberapa metode dalam SPK. Metode SPK dapat diimplementasikan dalam berbagai sektor, salah satunya adalah untuk mendukung gerakan masyarakat hidup sehat (GERMAS). Perilaku Hidup Bersih dan Sehat (PHBS) merupakan salah satu wujud dari GERMAS yang didorong pemeritah melihat kondisi penyebaran Covid-19 sepertis sekarang ini. Penelitian ini menganalisa performa metode SMART dan SAW ketika diberikan studi kasus yang sama, mengenai tingkar masyarakat yang memerlukan himbauan atau pemberdayaan. Hasil penelitian menunjukkan bahwa Metode SMART dapat digunakan walaupun ketika nilai terendah sebuah kriteria mencapai 0. Ketika menggunakan metode SAW perlu dilakukan perubahan pada jenis kriteria yang semula cost menjadi benefit, kemudia baru pada hasil akhir baru disorting secara ascending (dari nilai terkecil sampai terbesar). Ketika dilakukan hal tersebut kedua metode ini menunjukkan hasil yang sama dalam menentukan priotitas masyarakat yang perlu dilakukan pemberdayaan mulai dari Aleternatif 3, 5, 6, 4, 2, dan 1 .
\end{abstract}

(1 baris kosong, 10pt)

Kata kunci: metode SPK, SMART, SAW, GERMAS, Covid-19

\section{ANALYSIS OF SIMPLE MULTI ATTRIBUTE RATING TECHNIQUE (SMART) AND SIMPLE ADDITIVE WEIGHTING (SAW) METHODS IN SUPPORTING HEALTHY LIVING COMMUNITY MOVEMENTS}

\begin{abstract}
Various methods of Decision Support System (DSS) are widely used in helping determine the steps or decisions to be taken. Methods such as SAW, TOPSIS, PROMETHEE, WP, AHP, SMART are some of the methods in DSS. The DSS method can be implemented in various sectors, one of which is to support the healthy living community movement (GERMAS). Clean and Healthy Living Behavior (PHBS) is one form of GERMAS which is encouraged by the government to see the condition of the spread of Covid-19 as it is today. This study analyzes the performance of the SMART and SAW methods when given the same case study, regarding the level of society that requires appeal or empowerment. The results show that the SMART method can be used even when the lowest value of a criterion reaches 0 . When using the SAW method, it is necessary to change the type of criteria from cost to benefit, then the final results are sorted in ascending order (from the smallest to the largest value). When this is done, these two methods show the same results in determining community priorities that need to be empowered starting from Alternatives 3, 5, 6, 4, 2, and 1 ..
\end{abstract}

Keywords: DSS method, SMART, SAW, GERMAS, Covid-19

\section{PENDAHULUAN (huruf besar, 10pt, tebal)}

Berbagai metode dalam sistem pendukung keptusan (SPK), sekarang ini banyak digunakan untuk membantu manusia dalam menentukan langkah atau keputusan yang akan diambil. SAW, TOPSIS, PROMETHEE, WP, AHP, SMART merupakan beberapa contoh metode dalam SPK yang sering diimplementasikan diberbagai sektor (Muin, 2020). Salah satu contoh implementasi 
adalah untuk mendukung gerakan masyarakat hidup sehat (GERMAS) yang diukur melalui Perilaku Hidup Bersih dan Sehat (PHBS) yang diterapkan oleh masyarakat khususnya keluarga.

Keluarga merupak unit terkecil yang menjadi jangkauan pemerintah untuk melakukan kampanya dan sosialisasi gerakan masyarakat hidup sehat (GERMAS), dimana kegiatan ini menjadi ujung tombak untuk meningkatkan taraf kesehatan masyarakat khususnya di Indonesia (Instruksi Presiden RI, 2017)

Penelitian ini dilakukan untuk menganalisa performa dari dua buah metode SPK yaitu SMART dan SAW (Rasyid, dkk, 2017) ,ketika diberikan kasus yang sama mengenai penentuan prioritas masyarakat yang memerlukan pemberdayaan melalui indikator penilaian PHBS. (Kemenkes, 2011b).

\section{METODE PENELITIAN}

Dalam oenelitian ini menggunakan metode untuk menganalisa performa dari perbandingan metode SMART dan SAW. Flowchart metode penelitan dapat dilihat pada gambar 1 .

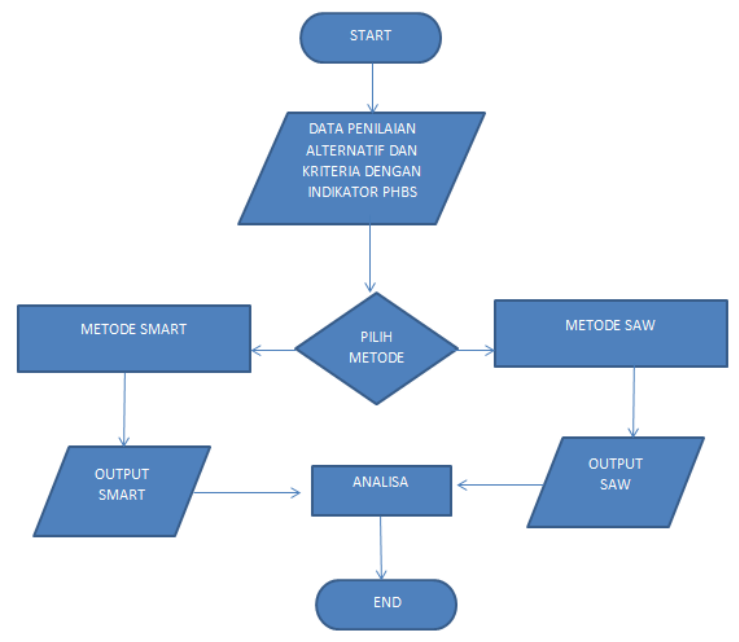

Gambar 1. Flowchar Metode Penelitian

Berikut ini penjelasan dari gambar 1.
a. Data yang digunakan adalah penilaian alternatif dan kriteria sesuai indikator PHBS.
b. Data diproses menggunnakan metode SMART dan SAW.
c. Hasil dari proses SMART dan SAW dianalisa
d. Tarik kesimpulan.

Pada persamaan (1), $f_{\text {baud }}$ merupakan frekuensi baud rate. SMOD adalah bit control dalam $P C O N$ (Power Mode Control Special Function Register),

\section{HASIL DAN PEMBAHASAN}

Data yang digunakan sesuai indicator PHBS dapat dilihat pada tabel 1. Kriteria yang digunakan 1. KIA dan Gizi , 2 Kesehatan Lingkungan, 3. Gaya Hidup, dan 4 Upaya kesehatan Masyarakat.

Tabel 1. Alternatif dan Nilai Kriteria

\begin{tabular}{ccccc}
\hline \multirow{2}{*}{ Alternatif } & $\begin{array}{c}\text { KIA } \\
\text { dan } \\
\text { Gizi }\end{array}$ & KL & \multicolumn{3}{c}{$\begin{array}{c}\text { Gaya } \\
\text { Hidup }\end{array}$} & UKM \\
\hline 1 & 4 & 5 & 4 & 2 \\
\hline 2 & 4 & 4 & 4 & 2 \\
\hline 3 & 4 & 5 & 4 & 0 \\
\hline 4 & 4 & 5 & 5 & 1 \\
\hline 5 & 4 & 5 & 5 & 0 \\
\hline 6 & 4 & 5 & 4 & 1 \\
\hline
\end{tabular}

Bobot untuk masing masing kriteria dapat dilihat pada tabel 2 .

Tabel 2. Bobot dan Kaidah Kriteria

\begin{tabular}{lcccc}
\hline Kriteria & $\begin{array}{c}\text { KIA } \\
\text { dan } \\
\text { Gizi }\end{array}$ & KL & $\begin{array}{c}\text { Gaya } \\
\text { Hidup }\end{array}$ & UKM \\
\hline Bobot & 1 & 2 & 3 & 4 \\
\hline Kaidah & Cost & Cost & Cost & Cost \\
\hline
\end{tabular}

Dalam metode SMART dan SAW sama sama ada penentuan jenis kriteria/kaidah, yaitu benefit dan cost.

a. Benefit ketika nilai semakin besar semakin baik.

b. Cost ketika nilai semakin kecil semakin baik.

Pada tahap ini dipilih cost karena mencari nilai paling kecil untuk diprioritaskan untuk diberikan penyuluhan/pemberdayaan.

\subsection{Metode SMART}

SMART (Simple Multi Attribute Rating Technique) dikembangkan oleh Edward pada tahun 1977. Merupakan langkah-langkah pembuatan keputusan multiatribut. SMART digunakan untuk mendukung pembuat keputusan dalam menentukan prioritas alternatif. Setiap alternatif memiliki kriteria yang nilainya akan dibandiangkan.

Langkah metode SMART adalah (Edward et al, 1994) :

a. Menentukan kriteria dan normalisasi bobot.

b. Menentukan nilai utility setiap alternative

c. Mengalikan masing-masing nilai utility dengan bobot yang sudah dinormalisasi. 


\subsubsection{Menentukan Normalisasi Bobot}

Dalam menentukan normalisasi menggunakan persamaan 1

Normalisasi Bobot $=\frac{W j}{\sum w j}$

Keterangan :

$\mathrm{Wj}=$ Bobot Kriteria $\mathrm{j}$

$\sum w j=$ Bobot total kriteria

Sehingga didapatkan perhitungan seperti pada table 3 .

Tabel 3. Normalisasi Bobot

\begin{tabular}{ccc}
\hline Kriteria & Bobot Kriteria & Normalisasi \\
\hline KIA & 1 & 0,100 \\
\hline $\begin{array}{c}\text { Kesehatan } \\
\text { Lingkungan }\end{array}$ & 2 & 0,200 \\
\hline Gaya Hidup & 3 & 0,300 \\
\hline $\begin{array}{c}\text { Upaya Kesehatan } \\
\text { Masyarakat }\end{array}$ & 4 & 0,400 \\
\hline
\end{tabular}

\subsubsection{Menentukan Utility}

Karena menggunakan kaidah cost maka dalam mencari nilai utility menggunakan persamaan 2

$U i(a i)=\frac{\text { Cmax }- \text { Cout }}{\text { Cmax }- \text { Cmin }}$

Keterangan :

Ui(ai) = nilai utility

Cmax = Nilai maksimal kriteria

Cout = Nilai kriteria sebuah alternatif

Cmin = Nilai minimal kriteria

Dengan menggunakan persamaan 2 didapatkan nilai utility dapat dilihat pada table 4

Tabel 4. Nilai Utility

\begin{tabular}{ccccc}
\hline Alternatif & $\begin{array}{c}\text { KIA } \\
\text { dan } \\
\text { Gizi }\end{array}$ & $\boldsymbol{K L}$ & $\begin{array}{c}\text { Gaya } \\
\text { Hidup }\end{array}$ & UKM \\
\hline 1 & 0,0 & 0,0 & 0,2 & 0,0 \\
\hline 2 & 0,0 & 0,2 & 0,2 & 0,0 \\
\hline 3 & 0,0 & 0,0 & 0,2 & 1,0 \\
\hline 4 & 0,0 & 0,0 & 0,0 & 0,5 \\
\hline 5 & 0,0 & 0,0 & 0,0 & 1,0 \\
\hline 6 & 0,0 & 0,0 & 0,2 & 0,5 \\
\hline
\end{tabular}


digunakan persamaan 3. Tabel rating nilai kecocokan dapat dilihat pada tabel 7

$$
R i j=\frac{X i j}{M a c X i j}
$$

Keterangan :

Rij = rating ke-i terhadap kriteria $\mathrm{j}$

Xij = Nilai I dari kriteria $\mathrm{j}$

MaxXij $=$ Nilai maksimal i dari kriteria $\mathrm{j}$

Tabel 7. Rating Kecocokan

\begin{tabular}{ccccc}
\hline \multicolumn{6}{c}{ Alternatif } & $\begin{array}{c}\text { KIA } \\
\text { dan } \\
\text { Gizi }\end{array}$ & KL & $\begin{array}{c}\text { Gaya } \\
\text { Hidup }\end{array}$ & UKM \\
\hline 1 & 1 & 1 & 0,8 & 1 \\
\hline 2 & 1 & 0,8 & 0,8 & 1 \\
\hline 3 & 1 & 1 & 0,8 & 0 \\
\hline 4 & 1 & 1 & 1 & 0,5 \\
\hline 5 & 1 & 1 & 1 & 0 \\
\hline 6 & 1 & 1 & 0,8 & 0,5 \\
\hline
\end{tabular}

\subsubsection{Mencari Nilai Preferensi}

Nilai preferensi (V) didapatkan dengan menggunakan persamaan 4 . Sehingga pada table 8 terlihat hasil perhitungan untuk mencarai nilai $\mathrm{V}$.

$$
V i=\sum_{j=i}^{n} W j * R i j
$$

\section{Keterangan :}

$$
\begin{array}{ll}
\mathrm{Vi} & =\text { Nilai preferensi alternatif } \\
\mathrm{Rij} & =\text { rating ke-i terhadap kriteria } \mathrm{j} \\
\mathrm{Wj} & =\text { Bobot Kriteria }
\end{array}
$$

\begin{tabular}{cc}
\multicolumn{2}{c}{ Tabel 8. Nilai V } \\
\hline Alternatif & $\boldsymbol{V i}$ \\
\hline 1 & 9,4 \\
\hline 2 & 9 \\
\hline 3 & 5,4 \\
\hline 4 & 8 \\
\hline 5 & 6 \\
\hline 6 & 7,4 \\
\hline
\end{tabular}

Karena dalam perhitungan menggunakan kaidah benefit maka dalam proses sorting dilakukan secara Ascending ( dari nilai kecil ke nilai yang paling bersar). Sehingga dapat dilihat pada table 9 .
Tabel 9. Tabel Prioritas

\begin{tabular}{ccc}
\hline Alternatif & PRIORITAS & HASIL \\
\hline 3 & $\mathbf{1}$ & 5,4 \\
\hline 5 & $\mathbf{2}$ & 6 \\
\hline 6 & $\mathbf{3}$ & $\mathbf{7 , 4}$ \\
\hline 4 & $\mathbf{4}$ & 8 \\
\hline 2 & $\mathbf{5}$ & 9 \\
\hline 1 & $\mathbf{6}$ & 9,4 \\
\hline
\end{tabular}

\section{KESIMPULAN DAN SARAN}

Dari hasil output kedua buah metode, dapat ditarik kesimpulan bahawa walaupun nilai yang dihasilkan berbeda tetapi hasil urutan prioritas menunjukkan hasil yang sama yaitu urutan Alternatif 3,5,6, 4, 2, dan 1 untuk mendapatkan penyuluhan atau pemberdayaan. Dalam penelitian ini muncul bebrapa kondisi diantaranya :

a. Dalam proses menggunakan metode SMART mampu menghitung menggunakan kaidah cost walaupun ada nilai kriteria yang mencapai angka 0. Karena dalam metode SMART menggunakan Range Angka Maksimal dan Minimal dalam proses perhitungannya

b. Metode SAW akan terjadi erorr ketika menggunakan kaidah kost dan terdapat nilai 0 .

c. Metode SAW dalam penelitian ini menggnakan kaidah benefit yang nantinya hasil akhir diurutkan secara Ascending ( dari nilai terkecil ke terbesar)

\section{DAFTAR PUSTAKA}

Edwards, W. and Barron, F.H., 1994. SMARTS and SMARTER: Improved simple methods for multiattribute utility measurement. Organizational behavior and human decision processes, 60(3), pp.306-325.

KEMENKES, 2011B. Promosi Kesehatan di Daerah Bermasalah Kesehatan. Kementrian Kesehatan Republik Indonesia.

Muin, A,A., 2020., Perbandingan Metode SAW Dan Metode SMART Dalam Pemilihan Kuliner Khas Kalimantan Selatan Terbaik, Technologia, Vol 11, No. 4 206-214

PRESIDEN RI., 2017. Instruksi Presiden Republik Indonesia No 1. Gerakan Masyarakat Hidup Sehat

Rasyid, M. and Si, M.B.S., 2017. Analisa Perbandingan Metode Simple Additive Weighting (SAW) DAN Metode Simple Multi Atribute Rating Technique (SMART) Dalam Pemberian Beasiswa (Studi Kasus Pemerintah Kota Batam). 